\title{
THE CHALLENGES AND OPPORTUNITIES OF WEB 2.0 ELECTIONS \\ The Case of Zimbabwe
}

\section{Limukani Mathe}

Limukani Mathe is a postdoctoral research fellow at the School of Communication, University of Johannesburg

\begin{abstract}
This study analyses different perspectives of the challenges and opportunities of using Web 2.0 technology with specific reference to Zimbabwe's 2018 general elections. It discusses digital tools and resources such as social networking sites (SNSs) and biometric voter registration (BVR) for the management of the voters' roll. The study includes in-depth interviews with several politicians and ZEC officials to discuss the challenges and opportunities of Web 2.0 in Zimbabwe's elections. Informed by theoretical concepts on technology and politics, the study establishes that technology is not a panacea but can be used as an apparatus. This study concludes that political institutions in Zimbabwe should reach consensus that the country will not conduct another election until electoral reforms are implemented because technology alone cannot overcome political challenges. Thus, the election monitoring body should be sufficiently credible to ensure a free and fair election.
\end{abstract}

Keywords: digital technologies, biometric voter registration (BVR), voters' roll, social networking sites (SNSs)

\section{INTRODUCTION}

This study aims to establish whether information technologies can make elections more inclusive and meaningful in Zimbabwe. The article focuses on the use of digital information technologies such as cellphones, internet facilities and other computer-based information systems, namely digital biometric technology for voter identification, software applications, Web 2.0, and related computer hardware during elections in Zimbabwe, particularly in 2018. 
The digital revolution started in the middle of the last century and is characterised by 'a fusion of technologies, blurring the lines between the physical, digital, and biological spheres' (Xu et al. 2018, p. 91). It is noteworthy that every technological revolution has brought about 'shifts in power, shifts in wealth, knowledge' and advanced democracy (Schwab 2015; Xu et al. 2018, p. 90). This study considers technology to consist of techniques, tools, technical objects or technical apparatus (van Jaarsveldt \& Wessels 2001).

Scholars such as Lee (2009) and Kim and Chen (2016) believe that technology such as the internet and social networking sites (SNSs) can promote democracy, discussion and the participation of citizens as well as improving voting patterns and experience. Debrah et al. $(2018$, p. 1) claim that the 'application of information technology (IT) in a democracy can promote efficient organisation, processing, communication, storage and retrieval of information needed by election management bodies'. Developed countries now use technologies for census, citizen registration, voter registration, as well as the counting and consolidation of votes (Xenakis \& Macintosh 2008). In an election, technologies such as online databases can facilitate the huge tasks of managing a voters' roll and even create accurate electoral rolls for polling stations. A decade ago, underdeveloped countries attempted to improve their electoral processes by embracing technology to prevent fraud or duplicate voting (Debra et al. 2018, p.2). Scholarly debate in Africa continues to question the impact of information technologies on offline realities where political systems are viewed as repressive (Mutsvairo 2013; Mutsvairo \& Sirks 2015).

Scholars such as Mozaffar and Schedler (2002) and Schaffer (2002) contend that developing democracies suffer electoral manipulations due to authoritarian leaders or incumbents circumventing electoral processes and the will of the people. Elections in Africa have often been chaotic and violent; for example, Kenya's 2017 elections were characterised by violence resulting in civil unrest. The 2019 elections in the Democratic Republic of Congo also saw delayed election results and protests. Many African countries also have revolutionary or liberation political parties in control of governments, and a history of longserving presidents. Opposition political parties struggle to win power and cry foul at bogus elections. Zimbabwe is among those African states with a troubled democracy whose elections have been viewed as unfair and unrepresentative with a rigged, inaccurate voters' roll and low voter turnout (Sithole \& Makumbe 1997; Hove \& Harris 2015).

\section{THE DIGITAL BIOMETRIC SYSTEM}

The use of digital biometric technology in voter registration is not unique to Zimbabwe as it has been utilised by several other African countries. In 2012 Ghana 
used the biometric system for voter registration and voter verification technology. Debra et al. (2018) studied the use of biometrics in Ghana's elections, and noted the system stimulated high voter participation, turnout and confidence in the electoral process. The biometric acted as 'forensic measure against election fraud such as impersonation and multiple voting' (Debra et al. 2018, p. 1). However, they add that there were many discrepancies arising from human error, slow voter verification and 'policy manipulation by polling officials', leading to a disputed election outcome.

In 2014 Namibia also used an electronic voting system (Alam \& Bokhari 2020). The Electoral Commission of Namibia (ECN) reported that the election had various technical issues such as the slow response of voters' verification resulting in the disenfranchisement of some voters who were unable to wait longer in the queue (ECN 2014). In 2015 Nigeria embraced new technologies such as the biometric card reader for 'direct data capturing for revalidation of voters' register, accreditation of eligible voters and permanent voters', making it impossible for a voter to cast the vote more than once (Nwagwu 2016, p. 305; Alam et al. 2020). Although that election was the country's first to be declared free and fair, some smart card readers had technical faults (Alam et al. 2020). The common problem with biometric technology is that voters can cast their ballots only at their registration centres or polling stations (Alam et al. 2020).

Biometric technology is an automated method that verifies and recognises voter's identity based on physiological features (Wayman 2000) such as fingerprints, retina, ear shape, hand vein and facial recognition (Rhodes 2003). The biometric system can recognise voice and signature (Jain et al. 2004) and links the person to his or her nationality, gender, district, or polling station, amongst others (Wayman 2000). The scanner is usually utilised to verify the user's characteristics and access is granted when his or her characteristics match with the stored or existing data.

Biometric identification does not guarantee accuracy or security as the system depends on the application and properties of the biometric characteristics (Uludag et al. 2004). The biometric process on its own depends on user interaction and can only perform within the user's capability or incapability (Wayman 2000) - in other words, an automated machine depends on the human factor. Prabhakar et al. (2003) argue that regardless of technological advantages, the fact that the biometric system depends on input devices means that it is subject to manipulation. Insufficient input, technological failure and underutilisation may fail to deliver the expected outcome (Jain et al. 2004). Debra et al. (2018, p. 2) argue that the failure of a biometric system to achieve an acceptable election outcome is not only caused by biometric technology malfunction but human error and policy manipulation by election officials'. In this light the article seeks 
to establish whether information technologies such as the biometric technology can be utilised for a meaningful or democratic election in Zimbabwe.

\section{ELECTIONS AND INFORMATION TECHNOLOGY IN ZIMBABWE}

Zimbabwe has had a series of violent elections since 1980 (Raftopoulos 2002, p. 2013). Scholars note that Zanu-PF has 'held electoral hegemony' (Sithole \& Makumbe 1997, p. 123) and has been the beneficiary of the 'winner takes-all' Electoral Act of 1987 (Sachikonye 2003, p. 120). Sithole and Makumbe (ibid.) argue that most of the elections held after 1980 had been a mere formality with low voter turnout due to voter apathy. This history of chaotic elections has been associated with the government's repressive media laws and control of state media. For instance, radio and television in Zimbabwe in both the pre- and post-colonial state have been used for hegemonic political purposes (Moyo 2005). From 2000 to 2002, the government of Zimbabwe enacted laws that barred media freedom and expression, namely the Broadcasting Services Act (BSA), the Public Order Security Act (POSA), the Access to Information and Protection of Privacy Act (AIPPA) and Criminal Law (Codification and Reform Act) (Raftopoulos 2002). The POSA restricted freedom of the press while AIPPA restricted publishing or access to any classified information (Moyo 2005, p. 12; Mugari 2008, p. 10). These laws affected freedom of the press throughout the elections. Zimbabwe still has only one television station, the Zimbabwe Broadcasting Cooperation (ZBC), few radio outlets and a modicum of print media houses.

The rise of the internet and Web 2.0 enhanced citizen's access to information. From the early 2000s, most of the online news outlets run by diasporans became alternative sources of information (Manganga 2012). Mutsvairo and Karam (2018, p. 5) posit that 'for many African states, it was nearly impossible to find alternative sources of news content before the digital revolution'. These online news sites dodged the repressive media laws in the country but the government of Zimbabwe considered them as a 'guerilla form of journalism' or 'terrorist media organisations' because they could report critical issues (Mugari 2008, p. 10). The digital revolution also enabled citizen participation in social networking sites (SNSs) such as Twitter and Facebook. Social networking sites became alternative platforms for political deliberation, promoting freedom of expression and association in digital spheres (Banda 2010; Mathe 2017). The social networking sites Twitter and Facebook also played a vital role in Zimbabwe's 2018 elections where political organisations, non-governmental organisations (NGOs) like Pachedu, civil society organisations (CSOs), national and international election observers like the European Union (EU) and Zimbabwe Election Support Network (ZESN) mobilised voters for biometric voter registration (Mwonzora 2020). 
Many stakeholders, political organisations and CSOs hoped that digital biometric voter registration (BVR) would eradicate the perennial problem of deceased, or 'ghost' voters on the voters' roll and halt electoral fraud (ZESN 2018). Other publics believed that the BVR system would boost public confidence, 'not only in the voter registration process but in the end product - the voters' roll' (Mwonzora 2020, p. 107). Thus, the adoption of BVR in Zimbabwe was supposed to counteract the perennial electoral challenges by promoting an inherently impartial and efficient election. It was believed that BVR 'would enhance citizens' trust and faith, therefore being in part responsible for the increase in the number of potential and interested voters' (Mwonzora 2020, p. 107). At first BVR had the support of the United Nations Development Programme (UNDP), civil society and all political stakeholders; however, the government of Zimbabwe took control of the system, creating political disharmony within the opposition (Zenda 2018).

Zimbabwe adopted BVR on 18 September 2017 with national registration on 10 October 2017 (Heal Zimbabwe Trust 2017). Zimbabwe Election Support Network $(2018$, p.12) notes that 'the exercise ran in four phases, from 10 October to 19 December 2017, before it was extended in a mop-up exercise between 10 January and 8 February 2018'. The election monitoring body, the Zimbabwe Electoral Commission (ZEC) had to extend the registration by 30 days due to public complaints that many potential voters had been excluded from the national BVR registration. Mwonzora (2020, p. 108) notes that the 'mobilisation of citizens to register as voters under the BVR system was, in part, a result of the intense social interactions among peers, colleagues, friends and strangers within virtual public spaces'. Hence, electoral challenges that occurred before and after the 2018 elections should be explored within the context that this was the first time Zimbabwe had gone to an election using digital biometric voter registration and a vigorous social media campaign for voter mobilisation and participation.

\section{A THEORETICAL VIEW OF TECHNOLOGY AND POLITICS}

The use of technologies in a democracy is still debatable, especially in Africa where political dynamics are challenging and diverse. This study uses the technological determinism paradigm and social construction of technology to analyse whether technologies can be used to make an election credible in Zimbabwe.

The technological determinism paradigm acknowledges that there is a relationship between technology and politics (Ellul 1990). Langdon Winner (1986) argues that 'properties of certain kinds of technologies are intrinsically linked to particular institutionalised patterns of power and authority'. Other scholars (Ott \& Rosser 2000; Hill \& Hughes 1999) have also shown that democratisation has been promoted by some technologies. Political communication studies highlight 
how digital technologies through social media have enhanced voter participation (Lee 2009; Nip 2006; Mathe \& Caldwell 2017). The internet and Web 2.0 have also enabled the interaction of political players and the public. Politicians can influence voting choices through digital media (Ott \& Rosser 2000). Through information technologies (ITs) citizens can be mobilised to participate and government can easily engage them in policy debates (Tettey 2001). Christopher Kedzie (1997) also notes that information technologies can dislodge 'entrenched social and political cleavages, by unleashing new patterns of citizen consciousness and civic engagement across the marginalised, hence generating new and decisive political outcomes' (Debra et al. 2018, p.3). Chiumbu (2015, pp. 9-10) argues that there can be 'no serious democracy without serious media technologies'.

Digital technologies in some parts of Africa have been used to promote citizen mobilisation and citizen-driven news at low cost (Chitanana 2020, p. 134). In 2009 and 2014, the electorate in South Africa made use of social media, both Facebook and Twitter, which in turn affected the results of the national elections (Dhawraj 2013). In 2015 and 2016, South Africa saw the eruption of student activism (\#FeesMustFall and \#RhodesMustFall) and this political activism used Facebook and Twitter as part of its mobilising campaigns (Mutsvairo \& Karam 2018). However, it is not always so with many southern African states 'whose governments do not tolerate any dissension within the public sphere, whether it is in the cybersphere, the media sphere or the physical realm, in terms of protesting' (Mutsvairo \& Karam 2018, p. 9). These authors also claim that governments in Africa respond by censoring and frustrating any dissent (Mutsvairo \& Karam 2018). For instance, in Zimbabwe the government responded harshly to social movements like \#ThisFlag and Tajamuka (Chitanana 2020).

Thus, the social construction of technology criticises the overreliance on information technologies for problem-solving in elections. This theory notes that technology on its own cannot solve societal problems in an election without a positive will for change. Robert Dahl (1989, p. 339) writes that 'the evolving technology is bound to be used somehow, for good or ill. It can be used to damage democratic values and the democratic process, or promote them'. Castells (2004) argues that technology alone cannot change political institutions and democratic processes, while Putnam (2000) claims that it can erode social capital. Thus scholars note the significance of the human factor in technology (Joerges 1999). For instance, in post-colonial African countries the state has used the media to promote the ruling party (Mutsvairo \& Karam 2018). Hoff (2000) argues that social actions determine the significance of technology. Castells (2001, p. 5) adds that 'the internet is a malleable technology that is susceptible to modification by its social practice, thereby leading to a whole range of potential social outcomes'. Given the social construction of technology and the technological determinism 
paradigm theory, this study therefore analyses perspectives on the challenges and opportunities of a Web 2.0 election in Zimbabwe.

\section{RESEARCH METHODOLOGY}

This study employed a qualitative research method through a semi-structured interview guide (see Appendix) to engage with ZEC officials, politicians and those representing political parties such as Zanu-PF, the MDCs (MDC-Alliance and MDC-T), People's Party (PP), and Zimbabwe People First (ZimFirst). Other minor political parties could not be reached; however, this does not distort the validity of the findings since the major stakeholders were involved. Qualitative research is viewed as 'rooted in a phenomenological paradigm which holds that reality is socially constructed through individual or collective definitions of the situation' (Firestone 1987, p. 17). A purposive and convenient sampling technique led to the interviewing of participants. Thus, a qualitative approach through in-depth interviews, including follow-ups, was able to obtain in-depth information from participants. The interviews were carried out between January 2020 and 10 May 2020. Some of the interviews were carried out telephonically due to difficulties in arranging face-to-face meetings.

Altogether a total of 30 politicians and 10 ZEC officials participated in this study. This study does not reveal the identities of the participants but their perspectives are considered important for analysis. Anonymity and confidentiality ensure that the participants' identities are not and should not be revealed in the study against their consent (De Vos 1998). Therefore, the perspectives reflected in this study exhibit the concerns or comments of major political parties and other politicians in Zimbabwe. Data was transcribed and coded in Nvivo11, a research tool to facilitate the thematic analysis of participants' perspectives.

\section{FINDINGS}

Participants had varied perspectives on the challenges and opportunities of a Web 2.0 election in Zimbabwe. The challenges and opportunities of such an election in Zimbabwe are linked to the voter registration process (BVR), election management and the role of ZEC, voting and the tabulation of results, political communication and outreach by political parties and candidates, and voters' responses to political messages.

\section{Biometric Voter Registration Process (BVR)}

Participants from the ruling party (Zanu-PF) noted that biometric voter registration was less cumbersome because it improved the level of transparency and 
enabled people to verify their registration status by crosschecking the voters' roll against the issued registration slip. Zanu-PF affiliated participants said that BVR was a huge improvement on the traditional voters' roll which was consistently found to have 'ghost' voters and could be manipulated. While some participants believed that BVR improved transparency in local elections, participants from the opposition pointed out that BVR was susceptible to manipulation by the ruling party.

Thus, BVR has its fair share of challenges with issues raised around the use of fictitious and double registrations. Participants from opposition political organisations commented:

- The voter's roll had many errors, some intended and some not. The refusal by the Zanu-PF government to avail the voters' roll to the opposition enabled them to manipulate the voters' roll in their favour. Voters found out that their names had been removed from the voter's roll on election day and there was nothing they could do.

- The purpose of the biometric voter registration was to have a clean biometric voter's roll; however it was open to abuse by the ruling party since their government runs the elections. They loaded names of their own people and issued voter registration slips to their supporters so that they could double vote. Without tightening these loopholes through election reform process the BVR will continue to be a double-edged sword.

- There were recurrent voter's roll duplications; despite the introduction of biometric technology, the voter's roll retained lots of irreconcilable discrepancies with some names of the deceased still appearing while those of the living appeared twice or more and some registered voters did not appear at all.

Inasmuch as the biometric system eased voter registration, the findings show that it could not curb the perennial challenges and allegations of 'ghost' voters and double registration. It is noteworthy that the BVR was susceptible to modification by the ruling Zanu-PF.

Other politicians argued that it remains a fallacy that the biometric registration of voters generated a biometric voters' roll. They pointed out that the ZEC failed to implement an accurate voters' roll, just as they had done in the 2013 elections. There were also complaints about the lack of timely access to the voters' roll. In 2018, the voters' roll was made available only a week before elections and had many errors. As a result, many political players questioned the accuracy of the voters' roll and had concerns about possible electoral fraud. A participant noted that: 
the 2018 elections were carried out with a new voters' roll but there were questions around access to the roll by opposition parties ahead of the polls. The questions raised around the credibility of the voters' roll had negative impacts on democracy as voters were discouraged from participation believing the outcome of the poll is predetermined.

\section{Election Management and the Compromised Role of ZEC}

The views of ZEC officials shed more light on the challenges faced during the biometric registration of voters, actual voting and the counting of votes. ZEC officers highlighted key challenges, namely (a) inadequate training of ZEC officers (b) the limited timeframe (c) challenges with the implementation of biometric technology (d) lack of transparency on the procurement of biometric technology and (e) recurrent voters' roll duplications. ZEC officers also noted that voter registration and elections were rushed, resulting in many errors and there was insufficient time allocated to the programme to prepare for a credible election, adding that training itself was inadequate. A participant made the following comment:

The training aspect left gaps between theory and practicals, like people were trained on the kit and less on placing voter using the alpha listings; hence people were erroneously posted in wrong wards and polling stations.

Another worrying factor raised by officials was that ZEC as the user system did not have absolute control of the biometric programme; the government of Zimbabwe under Zanu-PF retained control. A ZEC employee emphasised that 'there is still no known record of tender that was issued by government inviting bidders to supply the biometric technology to the government of Zimbabwe, thereby raising genuine opposition concerns'.

ZEC officers also expressed concerns about the lack of extensive voter education. A participant noted that voter education and subsequent adaptation or improvement of the biometric voter registration process was poorly communicated and in some instances opaque, and left a degree of suspicion about the whole process. A participant added that:

voter education midway the biometric voters' registration blitz did little to dispel the unintended inferences of politicking rumours that negatively affected the credibility and confidentiality of the data which was collected. 
Initially, biometric voter registration would have excluded aliens born in Zimbabwe had it not been for the High Court judgement which ruled that people with dual citizenship should be registered. Participants also emphasised that the proof of residence requirement for voter registration excluded mostly women and youths. One participant argued that the credibility of ZEC should depend on the (a) the voting system (b) the management of the election. There were accusations that ZEC failed to run a credible election because it was compromised by ZanuPF. Thus, the electoral governance was poorly done. A participant opined that:

The credibility of the Zimbabwe Elections Management body remains in doubt. Technology can improve processes but will never compensate [for] the lack of transparency by ZEC. Zimbabweans must prioritise the appointment of a credible independent elections body over technological advances... . Zimbabwe must invest in digital voting equipment ranging from voters' registration equipment, e-voting system to training of the personnel tasked with managing the voting process.

\section{Voting and the Tabulation of Results}

Voting and the tabulation of results was done manually in Zimbabwe's 2018 election just as it had been in all other previous elections. Participants highlighted the fact that BVR did not prevent all fraud as the actual voting and counting was done manually by government employees working under supervision. There were also reports of voters being turned away because their names could not be found in the voters' roll, and voter disenfranchisement was experienced across polling stations. According to a ZEC officer 'voter disenfranchisement was due to technical side of data cleaning which misposted the unfortunate voters'. Thus, the BVR could have misplaced some voters in the wrong polling stations. Participants also noted that the verification of voters at a polling station and the tabulation of results was manual. A participant noted that ZEC officials 'only asked for voters' conventional identity cards and there was no checking of voters' photographs or fingerprints as part of the voting process'. This means ZEC could not afford to implement the whole biometric system from voter registration to verification on election day. Politicians from the opposition party noted that:

The biometrics was [sic] of no use and gave no relevance to the tabulation of information at the end of the day. The ultimate electoral information from V11 and V23 forms were physically captured. It had issues of duplication where people were found to be in more than one voting space. 
Participants also noted that while most results were posted immediately outside the polling station, election observers found some polling stations which did not have results posted outside, and others where there were more voters who had cast their votes than were on the voters' roll. A participant noted that 'citizens exposed vote buying by sharing videos and photographs of the alleged malpractices and helping political parties to take counter measures'.

Given the challenges around manual voting, participants noted that digital voting might be progressive if it were not subject to hacking, and others indicated that Zimbabwe is technologically deficient in its ability to implement digital voting. For example, the government does not have functional first-class websites and few rural areas have either internet or access to digital platforms. On a different note, it was felt that personal information must be protected in the event of digital voting, because it is not safe for this to be available in a toxic political environment like Zimbabwe.

Digital voting was seen as capable of enhancing democracy through easy registration and verification of voters. A participant argued that electronic voting will probably reduce the number of spoilt ballot papers, improve the management of illiterate voters and speed up the process of vote counting. A Zanu-PF participant argued that although 'digital voting is prone to manipulation, it reduce[s] human errors and improve[s] transparency, hence manual voting remains safer'. Another participant added that 'electronic voting in an environment of distrust like Zimbabwe may result in more disputes as a result of the inability to easily identify any vote tempering in electronic voting machines'.

\section{Campaigning and Political Communication by Political Parties and Candidates}

Participants confirmed that Zimbabwe's media landscape is still dominated by the state with a relatively small private media sector, largely print, because of restricted licensing of private television and radio stations. The state media does not provide equal coverage to all political players. Participants opined that:

Digital technologies, through the internet, come as an alternative in Zimbabwe to offer opportunities for plurality as they can help media practitioners to circumvent stringent licensing regulations, high costs involved in setting up media channels and the generally restrictive legal environment. The mushrooming of online media platforms, some run by diasporans, to some extent helps improve plurality and gives a voice to groups that would otherwise be shut out of mainstream media.

The political environment as it currently stands doesn't support 
or enable a democratic election through digital media. The political space conflates one political party and the state. These monopolise the licensing of digital platforms to the exclusion of dissenting institutions. This has to be corrected in order to have clear and transparent use of digital media and technology platforms across the political divide.

This study finds that even in previous elections, the opposition relied largely on the alternative media (new media) for political communication. However, the use of new media such as social networking sites have been problematic in rural areas where people have poor internet connection and lack digital devices. Participants noted that most rural areas still depend on radio for information. A participant noted that:

Recent surveys show that more Zimbabweans are listening to the Voice of America's Zimbabwean service than to local radio stations, something that could be attributed to technology limitations on the part of the state-owned signal carrier and on the other hand access to technology by usually marginalised regions.

Although rural areas in Zimbabwe were viewed as disconnected from social media platforms such as Twitter and Facebook, participants noted that opposition political players relied more on social media to campaign or communicate. Campaign messages were accessed by divergent groups through cheaper platforms such as WhatsApp. Thus, social media enhanced voter education and reach by political groups more in urban areas and less in rural areas.

One participant indicated that 'information technology in Zimbabwe has been used to check and verify voter registration as well as transmit political campaigns directly to voters'. Some participants also acknowledged that during the biometric voter registration process, several civil and political organisations such as the Election Resource Centre (ERC) used social networking sites to encourage and motivate citizens. Most political parties, including Zanu-PF, used social media to mobilise citizens for rallies and turnout. Social media platforms such as WhatsApp were used to transmit immediate campaign messages because citizens could form digital communities that way. Thus, the Zimbabwe Election Commission was urged to use the short message services (SMS) and WhatsApp messaging as well as Facebook and Twitter for voter education campaigns, voter registration and verification.

Participants recommended that digital technologies be used to promote political campaigns and outreach. In addition, one participant said that: 
the cost of running digital media campaign varies with type ranging from very cheap to highly expensive. In underdeveloped countries the cheaper forms of digital media were WhatsApp and other mobile phone application that allow texting, video conferencing and group calls or group messaging substitute television ads, or physical rallies and these make sharing of information easier.

However, some participants complained that the ZEC should be transparent by using all digital platforms for voter education, registration and verification services to improve voter participation and turnout. It was noted that if political parties and candidates were provided with electronic voters' rolls on time, this would assist in their election campaigns, improve voter participation and turnout as well as reduce electoral fraud. There was much concern that the early release of the voters' roll should be accompanied by a fair voting process with cameras available at every polling station to monitor and reduce electoral fraud.

Nonetheless, participants emphasised that due to the limitations of infrastructure and the availability of electricity and signals in rural areas, reliance on digital technologies for a free and fair election remains problematic. One politician argued that the 'cost of handsets, data, electricity, and equipment remains expensive for rural communities who constitute $70 \%$ of all voters'. Thus, the challenge with social networking sites is that there are many rural communities with no access to digital media technologies. A different view was that the availability of alternative media in rural areas would help to dislodge much reliance on state-controlled media. A participant added:

Repressive governments the world over survive on restricting the flow of information and feeding citizens with propaganda to serve to keep them stay in power. The advent of social media along with a plethora of diverse digital media technologies would weaken the grip the dictatorship [has]on citizens' access to information.

Several participants opined that the solution is not necessarily the use and availability of digital technologies but a positive political will and electoral reforms. Others posited that electoral reforms can only work by stopping ZanuPF's interference in the voting process.

\section{Voters' Responses to Political Messages}

Due to polarisation in the country, political players noted that voter reaction to political messaging is subject to party affiliation. Though social media has 
emancipated most voters from sole dependency on state media for information, social media is easily misused for propaganda and fake news. For instance, some participants highlighted that Zanu-PF deployed what they call vakarashi (Shona term meaning invincibles) on Twitter to propagate party agendas and counterattack any opposing agenda.

Propaganda and political agitation increase considerably towards and during elections. While those connected through digital media and other technologies stay updated and informed, others in rural areas without the internet are described as being in the dark and intimidated by Zanu-PF. Participants noted that sometimes political parties, in particular the ruling party, use disinformation or misinformation to lure voters; for example, Zanu-PF has used torture and intimidation in rural areas in order to secure those votes (Raftopoulos 2002).

There were several allegations leveled against the ruling party which Zanu-PF affiliated politicians denied. The 2018 general elections were perceived as peaceful prior to the elections but many opposition politicians claimed that voter intimidation by Zanu-PF happened behind the scenes. Though the purpose of the BVR was to ensure that ZEC has an updated registry of voters, and to enable the elimination of ghost voters, some participants noted that the biometric system became a new tool of voter intimidation by Zanu-PF. For instance, some participants said that a day after the 2018 elections, Zanu-PF agents and the military went door to door recording BVR slip serial numbers, as they had instructed some voters to submit registration slip serial numbers and identity cards to ascertain who voted for them. Apparently some voters thought that the biometric system would assist Zanu-PF to gather their personal information and track them down using their photos, addresses and fingerprints. As a result, there was some doubt as to whether the BVR system was secure enough to protect their identities. Another participant mentioned that 'the generality of Zimbabweans could not understand this biometric technology, let alone those in rural areas'. He pointed out that the ZEC should have taken it upon themselves to educate Zimbabweans about biometric technology, how it works, and why it was chosen.

Moreover, the political environment was described as toxic and undemocratic. One participant opined that 'The involvement of the military and other security agencies has made it difficult to introduce technologies that enhance the quality of elections because of the organs' vested interests'.

President Mnangagwa's ascent to power was through a military takeover and Zimbabwe went to vote in 2018 without any electoral reforms. Some participants noted that this lack of electoral reforms resulted in voter apathy because Zanu-PF always manipulates the electoral process. Another participant further argued that 'As long as Zanu-PF maintains a grip on the electoral process any efforts invested to improve the voting process will be futile if electoral reforms are not addressed'. 
Thus, several comments indicate a lack of political will by Zanu-PF for electoral reform. This lack of electoral reform, violence, voter intimidation and torture, result in apathy and a low voter turnout.

\section{DISCUSSION}

The study established that technology on its own cannot be a panacea but is a tool to facilitate democratic processes. Previous literature and the findings of the study indicate that Zimbabwe still has a troubled democracy that cannot be resolved by technology alone. A Web 2.0 election on its own becomes a challenge in an environment where there is a lack of political will to reform or conduct a credible election. It is noteworthy that Web 2.0 technologies present many opportunities for a democracy but they are susceptible to misuse or manipulation in a toxic political contestation. Taking into consideration the social constructionist view of technology which claims that human action determines technology (Dahl 1989; Joerges 1999; Castells 2004), it would be far better to implement electoral reforms prior to any technological election. Technologies should be used as facilitation tools where social forces are ready for a political settlement.

It is evident from the findings of the study and previous literature that Zimbabwe needs to implement electoral reforms before even considering biometric voter registration or any other technologies. Literature and the findings of the study have shown that available digital media such as the state-controlled television (ZBC) are controlled by the ruling party and do not give equal coverage to all political players (Moyo 2005; Mugari 2008). Radio licensing is restricted and most often issued to Zanu-PF players. Mutsvairo and Karam (2018) have also shown that in post-colonial African countries the state has absolute control of the media in order to promote the ruling party. This alone indicates that other technologies in the country cannot escape state control. If state players can control the mainstream media for their own political communication, they are unlikely to allow technology to bypass their control. Hence, there is need to solve the political problem first before considering other technologies in an election, as these cannot provide any guarantee of a free and fair election where the political will is negative or biased.

Biometric voter registration was the object of political manipulation in Zimbabwe as the study has shown that Zimbabwe's ruling party took control of the biometric technology (Zenda 2018; Mwonzora 2020), and ZEC as an election monitoring body had no control of the system. Even today the sponsors of the biometric system remain unknown. Without transparency, the biometric system as a tool can be manipulated by the user. Prabhakar et al. (2003) posit that regardless of technological advantages, the biometric system is subject to 
manipulation because it depends on input devices. The user is capable of loading own data without the knowledge of a third party. Castells (2001, p. 5) also noted that technology is susceptible to modification by its social practice. The sociopolitical practice in Zimbabwe is tainted by a history of electoral manipulation; hence transparency is essential for any progressive democracy.

Although digital communication platforms such as social networking sites (SNSs) are today an alternative media for many Zimbabweans, a majority of the people in rural areas and even those in towns without digital privileges remain unconnected. The alternative media is viewed as the only technology that bypasses repressive media laws and government control but its impact is limited to those connected, who are considered a minority. Although social media and other digital media news platforms threaten the dominance of the ruling party, they can be misleading or are sometimes manipulated for political expediency. Castells (2001, p. 5) argues that 'the internet is a malleable technology', hence anyone can use it for his or her own purposes. Dahl (1989, p. 339) claims that 'the evolving technology is bound to be used somehow, for good or ill'. Thus, the solution is not necessarily in the use and availability of digital technologies, but rather in political will and electoral reform which are key to the progressive use of digital processes.

Digital technology can still be utilised as a tool for democratisation. This study notes that access to digital technologies in rural areas will enhance democracy and even minimise the level of manipulation caused by a lack of information. Digital technologies in other African contexts do enhance democracies where the political will is favourable. Hence, the Zimbabwean context does not negate the significance of these technologies as tools for democratic processes but only as a panacea for political problems.

\section{CONCLUSION}

This study concludes that Zimbabwe has complex political challenges that need positive political and electoral reforms for a democratic change. Main key challenges extracted from this study include the control of media by the government; repressive media laws; lack of access to digital technologies by citizens, especially in rural areas; the control of biometric technology by the state during elections; unfair media coverage; and lack of transparency by the election monitoring body, ZEC. Though digital technologies offer many progressive opportunities for democracy, they can be used for either good or evil.

Electoral reforms are paramount. Political institutions in Zimbabwe should agree on electoral reforms and ensure that the country will not go forward to the next election until reforms are implemented. The election monitoring body should be credible and the political environment conducive for a free and fair election. 


\section{Acknowledgement}

Funding: Global Excellence \& Stature 4.0 (GES4.0)

Disclosure: No conflict of interest

Alam, M \& Bokhari MU 2007, Information security policy architecture. In: ICCIMA'07: proceedings of the international conference on computational intelligence and multimedia applications (ICCIMA 2007), IEEE Computer Society, pp. 120-122.

Banda, F 2010, Citizen Journalism and Democracy in Africa, Highway Africa, Grahamstown.

Castells, M 2001, The Internet Galaxy: Reflections on the Internet, Business, and Society, Oxford University Press, Oxford.

Castells, M 2004, The Information Age: Economy, Society and Culture Volume II the Power of Identity, Blackwell, Malden.

Chitanana, T 2020, 'From Kubatana to\# ThisFlag: Trajectories of digital activism in Zimbabwe', Journal of Information Technology \& Politics, vol.17, no. 2, pp. 130-145.

Chiumbu, S 2015, ‘Public servant or censor? The South African Broadcasting Corporation in the era of political television advertising', Journal of African Elections, vol. 14, no. 1, pp. 149-170.

De Vos, AS (ed.) 1998, Research at grass roots. A primer for the caring professions, Van Schaik, Pretoria.

Debrah, EJ \& Owusu-Mensah, I 2018, 'Does the Use of a Biometric System Guarantee an Acceptable Election's Outcome? Evidence from Ghana's 2012 Election', African Studies, vol. 28, no. 3, pp. 1-23.

Dhawraj, R 2013, An investigation of the Democratic Alliance's political public relations campaign in the 2009 South African general elections, including how social networking site Facebook was leveraged to help increase the party's voteshare, MA thesis, UNISA.

Electoral Commission of Namibia (ECN), 2014, Available at https://www.ecn.na/ wp-con tent/uploads/2019/07/Post-Election-Report-2014.pdf

Ellul, J 1990, The Technological Bluff, Eerdmans Publishing Company, Grand Rapids. Firestone, WA 1987, 'Meaning in Method: The Rhetoric of Quantitative and Qualitative Research', Educational Researcher, vol.16, no. 7, pp. 16-21.

Heal Zimbabwe Trust 2017, Biometric Voter Registration (BVR) Process, Available at http:// kubatana.net/2017/10/30/ biometric-voter-registration-bvr-processupdate-6-20-28-october-2017/.

Hill, KA \& Hughes, JE 1999, 'Is the internet an instrument of global democratization?', Democratisation, vol. 6, no. 2, pp. 99-127. 
Hoff, J 2000, 'Technology and social change: The path between technological determinism, social constructivism and new institutionalism', in J Hoff, I Horrocks \& P Tops (eds), Democratic Governance and New Technology: Technologically Mediated Innovations in Political Practice in Western Europe, Routledge, London.

Hove, M \& Harris, G 2015, Free and fair elections: Mugabe and the challenges facing elections in Zimbabwe, Available at https://www.researchgate.net/ publication/281801607

Jain, AK, Ross, A \& Prabhakar, S 2004, 'An introduction to biometric recognition': IEEE Transactions on Circuits and Systems for Video Technology, vol.14, no.1, pp. 4-20.

Joerges, B 1999, ‘Do politics have artefacts?', Social Studies of Science, vol. 29, no.3, pp. 411-431.

Kedzie, CR 1997, Communication and Democracy: Coincident Revolutions and the Emergent Dictator's Dilemma, RAND, Santa Monica.

Kim, Y \& Chen, HT 2016, 'Social Media and Online Political Participation: The Mediating Role of Exposure to Cross-Cutting and Like-Minded Perspectives', Telematics and Informatics, vol. 33, no. 2, pp. 320-330.

Lee, YO 2009, 'Internet election 2.0? Culture, institutions, and technology in the Korean presidential elections of 2002 and 2007', Journal of Information Technology \& Politics, vol. 6, pp. 312-325.

Manganga, K 2012, The Internet as Public Sphere: A Zimbabwe Case Study (1999-2008), University of Stellenbosch.

Mathe, L \& Caldwell, M 2017, 'A Content Analysis of Readers' Comments on Political and Economic News Articles from Zimbabwe Online Media', KRE Journal of Communication, vol. 8, no.1, pp. 56-68.

Mathe, L 2017, 'A Network Analysis of Conversational News Readers on Political and Economic Zimbabwe Online Media', KRE Journal of Communication, vol. 8, no.1, pp. 44-55.

Moyo, D 2005, 'From Rhodesia to Zimbabwe: Change without change? Broadcasting', In H Melber (ed.), Media, public discourse and political contestation, Nordic Africa Institute, Uppsala.

Mozaffar, S \& Schedler, A 2002, 'The comparative study of electoral governance - Introduction', International Political Science Review, vol. 23, no.1, pp. 5-27.

Mugari, ZE 2008, Ambivalence and Activism: Towards a Typology of the Interrogating the form and content of refracted public realms in polarised societies: How have the media performed in the run-up to Zimbabwe's 2008 national elections, Codesria, Gweru.

Mutsvairo, B, 2013, Power and participatory politics in the digital age: Probing the use of new media technologies in railroading political changes in Zimbabwe. Doctoral dissertation, Leiden University Institute for History, Faculty of Humanities, Leiden University. 
Mutsvairo, B (ed) 2016, Digital Activism in the Social Media Era: Critical Reflections on Emerging Trends in Sub-Saharan Africa, Springer, Cham, $\mathrm{CH}$.

Mutsvairo, B \& Karam B, 2018, Perspectives on Political communication in Africa, Palgrave Macmillan, London.

Mutsvairo, B \& Sirks, L 2015, 'Examining the contribution of social media in reinforcing political participation in Zimbabwe', Journal of African Media Studies, vol. 7, no. 3 .

Mwonzora, G 2020, 'Social media and citizen mobilisation in the biometric voter registration (BVR) process in Zimbabwe', Journal of Contemporary African Studies, vol. 38, no. 1, pp.103-120.

Nip, JYM 2006, 'Exploring the second phase of public journalism', Journalism Studies, vol. 7, no.2, pp. 212-236.

Nwagwu, EJ 2016, 'Information and Communication Technology and Administration of 2015 General Election in Nigeria, Mediterranean Journal of Social Sciences, vol.7, no.4.

Ott, D \& Rosser, M 2000, 'The electronic republic? The role of the internet in promoting democracy in Africa', Democratisation, vol. 7, no.1, pp.137-156.

Prabhakar, S, Pankanti, S \& Jain, AK, 2003, 'Biometric recognition: Security and privacy concerns', IEEE Security \& Privacy Magazine, vol. 1, no. 2, pp. 33-42.

Putman, RD 2000, Bowling Alone: The Collapse and Revival of American Community, Simon \& Schuster, New York.

Raftopoulos, B 2002, 'Briefing: Zimbabwe's 2002 Presidential Election', African Affairs, vol.101, no. 404, pp. 413-426.

Rhodes, KA 2003, Information Security: Challenges in Using Biometrics, US General Accounting Office.

Sachikonye, LM 2003, 'The Electoral System and Democratisation in Zimbabwe since 1980', Journal of African Elections, vol. 2, no.1.

Schaffer, FC 2002, 'Might cleaning up elections keep people away from the polls? historical and comparative perspectives', International Political Science Review, vol. 23, no.1, pp.69-84.

Schwab, K 2015, The Fourth Industrial Revolution: What It Means and How to Respond, Available https://www.foreignaffairs.com/articles/2015-12-12/fourthindustrial-revolution.

Sithole, M \& Makumbe, J 1997, ‘Elections in Zimbabwe: The ZANU (PF) Hegemony and Its Incipient decline', African Association of Political Science, vol. 2, no.1, pp. 122-139.

Tettey, JW 2001, 'Information technology and democratic participation in Africa', in SN Ndegwa (ed.), A Decade of Democracy in Africa, Brill, Leiden.

Uludag, U, Pankanti, S, Prabhakar, S \& Jain, AK, 2004, Biometric cryptosystems: Issues and challenges. Proceedings of the IEEE vol. 92, no.6, pp. 948-959. 
Van Jaarsveldt, LC \& Wessels, JS 2001, 'The application of WEB 2.0 Technologies by the South African Government', Administratio Publica, vol. 19, no. 4, pp. 63-79.

Wayman, J 2000, A Definition of Biometrics National Biometric Test Center Collected Works 1997-2000, San Jose State University, San Jose, Calif.

Winner, L 1986, The Whale and the Reactor: A Search for Limits in an Age of High Technology, University of Chicago Press, Chicago.

Xenakis, A \& Macintosh, A 2008, 'A framework for the analysis of procedural security of the e-electoral process', International Journal of Public Administration, vol.31, pp. 711-729.

Xu, M, David, JM \& Kim, SH 2018, 'The Fourth Industrial Revolution: Opportunities and Challenges', International Journal of Financial Research, vol. 9, no. 2.

ZEC 2018, Biometric Voter Registration, Available at https://www.zec.org.zw/pages/ biometric_voter_registration.

Zenda, C 2018, Available at https://www.trtworld.com/magazine/how-atechnological-solution-backfired-in-zimbabwe-s-elections-19430 .

ZESN 2018, Report on the 30th July 2018 Harmonized Election, Advance Copy, Zimbabwe Election Support Network, Harare. Available at http://www. veritaszim.net/sites/veritas_d/files/ZESN-Report-on-the-30-July-2018Harmonised-Election.pdf. 


\section{APPENDIX}

a) How can the digital technologies enhance democracy in Zimbabwe?

b) In what way can digital technologies increase voters' participation, voter turnout and reduce electoral fraud?

c) Did the social media campaigns enhance voter turnout for the 2018 election?

d) How did political players utilise digital media for political communication?

e) What were the challenges implementing the biometric voter registration (BVR) for 2018 elections?

f) Any challenges in terms of voter verification at polling stations?

g) Did the Biometric Voters' Roll 2018 elections assist the electorate or promote a democratic election?

h) How true that 2018 and 2013 elections were carried out without the electronic voters' roll? How does this affect a democratic election?

i) Do you think it will be progressive to digital the voters' roll or implement digital/e-voting?

j) Is the political sphere conducive for a democratic election through digital technologies? 